\title{
Editorial
}

Nicholas M. Greene*

\section{A new post: laureate of the history anaesthesia}

The study of the history of anaesthesia is an important, worthy and honourable calling that adds to the richness of our specialty. To promote recognition of the importance of the study of the history of anaesthesia and to recognize scholars who have made singular contributions to the field, the Trustees of the Wood Library Museum of Anesthesiology (WLM), an affiliate of the American Society of Anesthesiology, have initiated a new post, that of WLM Laureate of the History of Anesthesia.

Laureates will be selected on the basis of a demonstrable record of outstanding original contributions to the study of the history of anaesthesia as evidenced by published monographs and articles in peer-reviewed journals. The award will be international. All physicians, anaesthetic and non-anaesthetic, as well as non-physician historians are eligible for nomination regardless of where they live. Nominations may be submitted by anyone, including one's self. They must include three copies of the nominee's curriculum vitae and complete bibliography together with three copies of a signed covering letter describing the basis for the nomination as well as the names and full addresses of four persons to be contacted as references.

Selection of the WLM Laureate will be made every four years beginning in 1995 and will be announced in October during the annual meeting of the American Society of Anesthesiology. The awardee will be honoured by presentation of a suitably inscribed medal at the time of the next year's annual meeting of the American Society of Anesthesiologists with the honoree's expenses being provided by the WLM. The first award will thus be made in 1996. Though accompanied by neither an honorarium nor prescribed duties, the post of Laureate carries with it the expectation that the Laureate will remain active in publication of historical materials and will contribute to the education of anaesthetists and others by lectures and participation in panels and seminars.

Nominations must be delivered to the Chair, WLM Laureate Committee, Wood Library Museum, $520 \mathrm{~N}$. Northwest Highway, Park Ridge, Illinois 60068-2573 before July 1 of the year preceding the year divisible by

*Trustee, Wood Library - Museum of Anesthesiology. four in which the award is to be made. e.g., before July 1,1995 for presentation of the award by 1996 . Questions regarding the programme may be addressed to the Chair of the WLM Laureate Committee at the above address.

In the absence of a suitably qualified nominee, the Laureate award will not be made every four years, but in no case will the award be made in years not devisable by four.

\section{Du nouveau: un lauréat en histoire de l'anesthésie}

Pour notre profession, l'étude de l'histoire de l'anesthésie est importante et enrichissante. Pour l'encourager et pour récompenser nos collègues qui ont contribué à l'écrire, les fondés de pouvoir du Wood Library Museum of Anesthesiology (WLM), en association avec l'American Society of Anesthesiology, ont créé un nouveau prix, celui de lauréat en histoire de l'anesthésie.

Les lauréats seront choisis pour leur contribution dans ce domaine et sur présentation de monographies et d'articles acceptés par des comités de lecture et publiés dans des journaux reconnus. Le prix sera international. Tous les mèdecins, anesthésistes ou non, les historiens avec ou sans affiliation médicale, sont éligibles indépendamment de leur lieu de résidence. Les candidatures peuvent être soumises par tous, incluant l'aspirant. Elles doivent s'accompagner de trois copies du curriculum vitae du candidat avec une bibliographie complète et trois copies d'une lettre d'accompagnement décrivant les motifs de la candidature ainsi que les noms et adresses de quatre personnes qui répondent du candidat.

Le lauréat WLM sera choisi à tous les quatre ans à compter de 1995 et ce choix sera annoncé en octobre de l'année suivante pendant la réunion annuelle de l'A- 
merican Society of Anesthesiology. Le récipiendaire recevra une médaille au congrès annuel de l'ASA et ses dépenses seront défrayées par le WLM. La première attribution aura donc lieu en 1996. Sans jouir d'honoraires et d'autres bénéfices financiers, le lauréat devrait idéalement continuer à publier des travaux sur l'histoire et contribuer à l'enseignement des anesthésistes et autres par des conférences et une participation active à des discussions et des séminaires.

Les mises en candidature doivent être dirigées à Chair, WLM Laureate Committee, Wood Library Museum, 520 N. Northwest Highway, Park Ridge, Illinois 60068-2573 avant le premier juillet de l'année précédant l'année divisible par quatre de la présentation de la récompense: par exemple, avant le premier juillet 1995 pour la présentation du prix de 1996. Toute question concernant cette activité doit être adressée à la présidence du comité du laureat WLM à l'adresse qui paraît plus-haut.

En absence d'un candidat idoine, le prix ne sera pas accordé cette année-là et il ne sera jamais attribué aux années non divisibles par quatre. 